http://dx.doi.org/10.7197/1305-0028.71839

\title{
Blood group distribution of donors and patients admitted to the Blood and Transfusion Center of Cumhuriyet Uni- versity Hospital
}

\section{Cumhuriyet Üniversitesi Sağlık Hizmetleri Uygulama ve Araştırma Hastanesi Kan/Tranfüzyon Merkezi'ne başvuran donörlerin/hastaların kan grubu dağılımı}

\author{
Erdoğan Doğan ${ }^{1}$, *Gülgün Sevimligül ${ }^{2}$, Cem Çelik $^{3}$, Mehmet Şencan $^{4}$ \\ ${ }^{1}$ Laboratory Of The Blood Transfusion Center, Cumhuriyet University School of Medicine \\ ${ }^{2}$ Nursing Research and Project Development Department, Cumhuriyet University Hospital \\ ${ }^{3}$ Department of Microbiology, Cumhuriyet University School of Medicine \\ ${ }^{4}$ Department of Hematology, Cumhuriyet University School of Medicine \\ Corresponding author: Bilim. Uzm. Gülgün Sevimligül, Hemşirelik Araştırma ve Proje Geliştirme De- \\ partman1, Cumhuriyet Üniversitesi Tıp Fakültesi Hastanesi, TR-58140 Sivas/Türkiye \\ E-mail: gulgun_mail@ hotmail.com.tr \\ Received/Accepted: October 27, 2014/February 23, 2015
}

\section{SUMMARY}

Objective: Blood group is a classification of human blood based on the antigenic types on the surface of red blood cells (erythrocytes). ABO and Rh blood group systems are widely used in our country and in the world. We aim to determine distribution of the ABO and Rh blood groups in our region using the results of blood group tests studied by the blood/transfusion center of Cumhuriyet University Hospital in our study.

Method: The blood groups of 99.207 subjects were examined based on data obtained blood/transfusion center admitted to the in our hospital between January 2009 and December 2013 in a five-year period as retrospectively. The blood groups was determined using tube agglutination method, microcolon method and microplate automatic blood group method in EDTA-containing blood samples and the weak D was studied in subjects with Rh factor negative. Subjects are evaluated only once for blood group during the study period. Repeated examples belong to the same individuals were excluded from the study.

Results: The rates of the blood groups were determined as $43.8 \% \mathrm{~A}, 31.8 \% \mathrm{O}, 16.4 \% \mathrm{~B}$ and $8.0 \%$ $\mathrm{AB}$ according to the results of our region in the study period. In addition, $87 \%$ of subjects was $\mathrm{Rh}$ positive and $13 \%$ was Rh negative. Most common blood group was A Rh positive (37.9\%) while the least common type was AB Rh negative (1\%) in our region.

Conclusion: Blood is vital for the human body. Blood groups may vary between regions. Therefore, regional data must be determined and to be updated with specific time intervals. Distribution of blood groups in our blood/transfusion center is compatible with distribution of blood groups in Turkey. In addition, statistics of blood group distribution should be reviewed and critical level of blood group stock should be determined by the authorites of blood/transfusion center.

Keywords: AB0 blood group system, Rh factor, Sivas.

\section{ÖZT}

Amaç: Kan grupları, kanda bulunan kırmızı kan hücrelerinin (eritrositlerin) üzerinde bulunan antijen çeşitlerine göre yapılan bir sınıflama sistemidir. Ülkemizde ve dünyada yaygın olarak kullanılmakta olan kan grubu sistemleri, AB0 ve Rh sistemleridir. Çalışmamızda Cumhuriyet Üniversitesi Sağlık Hizmetleri Uygulama ve Araştırma Hastanesi Kan merkezi/transfüzyon merkezinde çalışılan kan grubu testlerinin sonuçlarından faydalanılarak bölgemizdeki AB0 ve Rh 
kan gruplarının dağılımını belirlemeyi amaçladık.

Yöntem: Çalışmamızda Ocak 2009 ile Aralık 2013 tarihleri arasındaki beș yıllık dönemde merkezimize başvuran 99207 kişinin kan grupları Kan merkezi/transfüzyon merkezi verilerinden geriye dönük olarak incelenmiștir. Kan grubu tayini EDTA'lı kan örneklerinde tüp aglütünasyon yöntemi, mikrokolon yöntemi ve mikroplak otomatik kan grubu cihazıyla yapılmış ve Rh faktörü negatif olanlara zayıf D çalışılmıştır. Çalışma süresi içerisinde merkezimizde kan grupları tespit edilen kişiler bir defa değerlendirilmiş olup, aynı bireylere ait tekrarlanan örnekler çalışma dışı tutulmuştur.

Bulgular: Araştırılan süre içinde bölgemizde elde ettiğimiz sonuçlara göre kan gruplarının; $\% 43,8$ 'inin $\mathrm{A}, \% 31,8$ 'inin $0, \% 16,4$ 'ünün $\mathrm{B}$ ve $\% 8,0$ 'ının $\mathrm{AB}$ olduğu belirlenmiştir. Ayrıca kişilerin \%87'sinin Rh pozitif, \%13'ünün ise Rh negatif olduğu tespit edilmiştir. Çalışmamızdan elde edilen verilerde bölgemizde en sik bulunan kan grubunun A Rh pozitif $(\% 37,9)$, en az bulunan kan grubunun ise AB Rh negatif (\%1) olduğu tespit edilmiştir.

Sonuç: Kan insan için hayati öneme sahip olan bir sıvıdır. Kan grupları bölgeler arasında farkl11ıklar gösterebilmektedir. Yapılacak çalışmalar ile bölgesel verilerin ortaya konulması ve belirli zaman aralıkları ile güncellenmesi gerekmektedir. Merkezimizde saptanan kan grubu dağılımı Türkiye ortalamalarıyla paralellik göstermektedir. Ayrıca kan merkezlerinin bulundukları illerdeki kan grubu dağılımlarını gözden geçirerek kritik stok kan seviyeleri belirlemelerinin faydalı olacağını düşünmekteyiz.

Anahtar sözcükler: AB0 kan grubu sistemi, Rh faktörü, Sivas

\section{INTRODUCTION}

Blood has been mysterious and mesmerizing for humans since ancient times ${ }^{1-4}$. According to the Roman and Greek sources, it was used for the treatment of epilepsy for the first time in 160-200 A.D. Inb al-Nafis defined the microcirculation in 1260, the blood circulation was discovered and the earliest known blood transfusion trials were begun by the English Doctor William Harvey in 1628 , and the first transfusion between people was carried out by James Bundell in $1818^{3,5-7}$. As of 1900 , firstly the blood groups ( $\mathrm{AB} 0$ ) then the $\mathrm{Rh}$ factor were discovered by the Austrian doctor Karl Landsteiner $^{8-15}$.

Blood is a biological material, which circulates in the vessel system, consists of erythrocyte, leucocyte, thrombocyte cells and plasma, perfuses the organs, can't be obtained artificially and the source of which is the human ${ }^{1,2,10,11,15-17}$.

Blood groups are the classification systems that are formed considering the antibodies within the blood ${ }^{1,2,18-20}$. The blood group systems widely used in our country and the world are $\mathrm{AB} 0$ and Rh systems. According to the $\mathrm{AB} 0$ group system, the blood groups are classified as $\mathrm{A}, \mathrm{B}, \mathrm{AB}$ and $\mathrm{O}$ groups and to the Rh system, as Rh D Positive (+) and Rh D Negative (-). Blood groups are determined as per the antigens on the surface of erythrocytes and the antibodies in the plasma. There are many antigens on the surface of the erythrocytes. A and B antigens are stronger. The $\mathrm{A}$ group has type A antigen, the $B$ group has type $B$ antigen and the $A B$ group has both type $A$ and $B$ antigens. And there are no antigens on the surface of the erythrocytes in the $\mathrm{O}$ group ${ }^{1,2,5,9,12,13,18-21}$.

The $\mathrm{Rh}$ factor is an antigen in the outer cell membrane of the erythrocytes. It was seen that the anti-serum, which had been obtained by the transfusion of the blood taken from Macacus Rhesus monkeys into rabbits, agglutinated the human serums. This antigen was named as the $\mathrm{Rh}$ antigen as dedicated to Rhesus monkeys. The existence of type $\mathrm{D}$ antigen of the $\mathrm{Rh}$ factor in blood is named as Rh positive (+) and the nonexistence as $\mathrm{Rh}$ negative (-) blood $^{5,10,18}$.

Blood can be life-saving for the individuals who lose blood after accidents, injuries and operations, patients who receive treatment for diseases such as hemophilia, leucemia and aplastic anemia and cancer, and pregnant women ${ }^{22-24}$. Blood transfusion is an indispensable part of medical treatments ${ }^{16}$. Determination of the blood groups is the first stage of the blood transfusion. Again, determination of the blood groups is very important in situations such as genetic and anthropological studies, judicial cases and $\mathrm{Rh}$ incompatibilities. Distribution of the blood groups may differ with regard to 
different geographical regions ${ }^{25}$. In our study, we aimed at determining the distributions of $\mathrm{AB} 0$ and $\mathrm{Rh}$ blood groups and making contributions to the literature in this sense.

\section{MATERIAL AND METHODS}

The blood groups of 99207 people, who applied to the blood/transfusion center of Cumhuriyet University, Health Services Application and Research Hospital between January 01, 2009 and December 31,2013 , were examined retrospectively by using the data of our center. People, whose blood groups were determined in our center within the study period, were evaluated once and the repeated samples of the same individuals were excluded from the study. Blood group assignments were carried out with the tube agglutination, microcolon and microplaque methods and the weak D test was applied to the $\mathrm{Rh}$ negative ones. The tube agglutination method in blood samples with EDTA.

The blood samples were put into the tubes with anticoagulants. One drop from each of anti-A, anti-B and anti-D was dripped into three clean and labeled glass tubes. One drop was added into each test tube from the erythrocyte suspension in $2-5 \%$ physiological saline. The tubes were gently mixed and centrifuged. The agglutination existence was assessed as positive.

In this method, $5 \%$ erythrocyte suspension was prepared and $10 \mu 1$ was added into the board wells (Ortho Clinical Diagnostic, USA). The evaluations were made through the implementation of the test as per the study procedures of the manufacturer.

Cellbind (the Netherlands) test kits were used in the Emotype (Italy) device for this study. The examinations were carried out as per the study procedures of the manufacturer.

\section{The Weak D Test}

Some erythrocytes carry a D antigen, which is too weak to be directly agglutinated by many anti-Ds. This weakness of the $\mathrm{D}$ antigen can be defined most clearly with the indirect antiglobulin test (IAT) after the incubation of the test erythrocyte with the anti-D. This test is based on the principle of the incubation of test erythrocytes with the anti-D at the indirect antiglobulin phase ${ }^{26}$. One drop of anti-D was dripped into a clean tube marked for this process. One drop of 2-5\% erythrocyte suspension was added on it. The tubes were slightly mixed and incubated at $37{ }^{\circ} \mathrm{C}$ for 15-30 minutes. The tubes were centrifuged and checked for whether agglutination occurred. The tests were assessed with a control tube. Agglutination was evaluated as positive in the test tube, negative in the control tube and the test result as $\mathrm{Rh}$ (D) positive. The samples with negative test results were washed 3-4 times with physiological saline. The tubes were slightly mixed and centrifuged after the addition of antiglobulin into the test tube as per the suggestion of the manufacturer. At the end of the process, the test was reported as positive in case of the agglutination existence in the tube and negative if not so ${ }^{26}$. This study was conducted by the decision of the Ethics Committee, Cumhuriyet University.

\section{RESULTS}

In our study, the blood groups of 99207 people, who applied to our center, were separately examined as per the years between the dates stated, and no important difference was observed between the years in terms of blood groups distribution. According to the five-year average results that we assessed during our study, A Rh (+) was determined as $37.9 \%$, A Rh (-) as $5.9 \%, \mathrm{~B} \mathrm{Rh}(+)$ as $14.4 \%$, B Rh (-) as $2.0 \%, \mathrm{AB} \mathrm{Rh}(+)$ as $7.0 \%, \mathrm{AB} \mathrm{Rh}(-)$ as $1.0 \%, 0 \mathrm{Rh}(+)$ as $27.7 \%$ and $0 \mathrm{Rh}(-)$ as $4.1 \%$. The distribution of the blood groups within years is given in Table 1. 
Table 1: Distribution of blood groups by year.

\begin{tabular}{|c|c|c|c|c|c|c|c|}
\hline \multicolumn{2}{|l|}{ Blood group } & 2009 & 2010 & 2011 & 2012 & 2013 & Total \\
\hline \multirow[t]{2}{*}{$\mathrm{A} R \mathrm{Rh}(+)$} & $\mathrm{n}$ & 6893 & 8531 & 8580 & 8544 & 4967 & 37.515 \\
\hline & $\%$ & 38.0 & 38.2 & 38.3 & 37.5 & 36.4 & 37.9 \\
\hline \multirow[t]{2}{*}{ A Rh (-) \% } & $\mathrm{n}$ & 1064 & 1258 & 1352 & 1322 & 814 & 5.810 \\
\hline & $\%$ & 5.9 & 5.7 & 6.0 & 5.8 & 6.0 & 5.9 \\
\hline \multirow{2}{*}{$\mathrm{B} \mathrm{Rh}(+) \%$} & $\mathrm{n}$ & 2583 & 3131 & 3079 & 3377 & 2118 & 14.288 \\
\hline & $\%$ & 14.3 & 14.1 & 13.8 & 14.8 & 15.6 & 14.4 \\
\hline \multirow[t]{2}{*}{ B Rh (-) \% } & $\mathrm{n}$ & 369 & 457 & 423 & 507 & 267 & 2.023 \\
\hline & $\%$ & 2.0 & 2.1 & 1.9 & 2.2 & 2.0 & 2.0 \\
\hline \multirow{2}{*}{$\begin{array}{l}\mathrm{AB} \mathrm{Rh}(+) \\
\%\end{array}$} & $\mathrm{n}$ & 1157 & 1529 & 1622 & 1546 & 1100 & 6.954 \\
\hline & $\%$ & 6.3 & 6.9 & 7.2 & 6.8 & 8.0 & 7.0 \\
\hline \multirow[t]{2}{*}{$\mathrm{AB} \mathrm{Rh}(-) \%$} & $\mathrm{n}$ & 173 & 263 & 217 & 211 & 166 & 1.030 \\
\hline & $\%$ & 0.9 & 1.2 & 1.0 & 0.9 & 1.2 & 1.0 \\
\hline \multirow[t]{2}{*}{$\mathrm{ORh}(+) \%$} & $\mathrm{n}$ & 5160 & 6292 & 6223 & 6289 & 3582 & 27.546 \\
\hline & $\%$ & 28.4 & 28.2 & 27.8 & 27.6 & 26.3 & 27.7 \\
\hline \multirow[t]{2}{*}{ O Rh (-) \% } & $\mathrm{n}$ & 720 & 833 & 907 & 978 & 603 & 4.041 \\
\hline & $\%$ & 4.0 & 3.7 & 4.0 & 4.3 & 4.4 & 4.1 \\
\hline Total & $\mathbf{n}$ & 18.119 & 22.294 & 22.403 & 22.774 & 13.617 & 99.207 \\
\hline
\end{tabular}

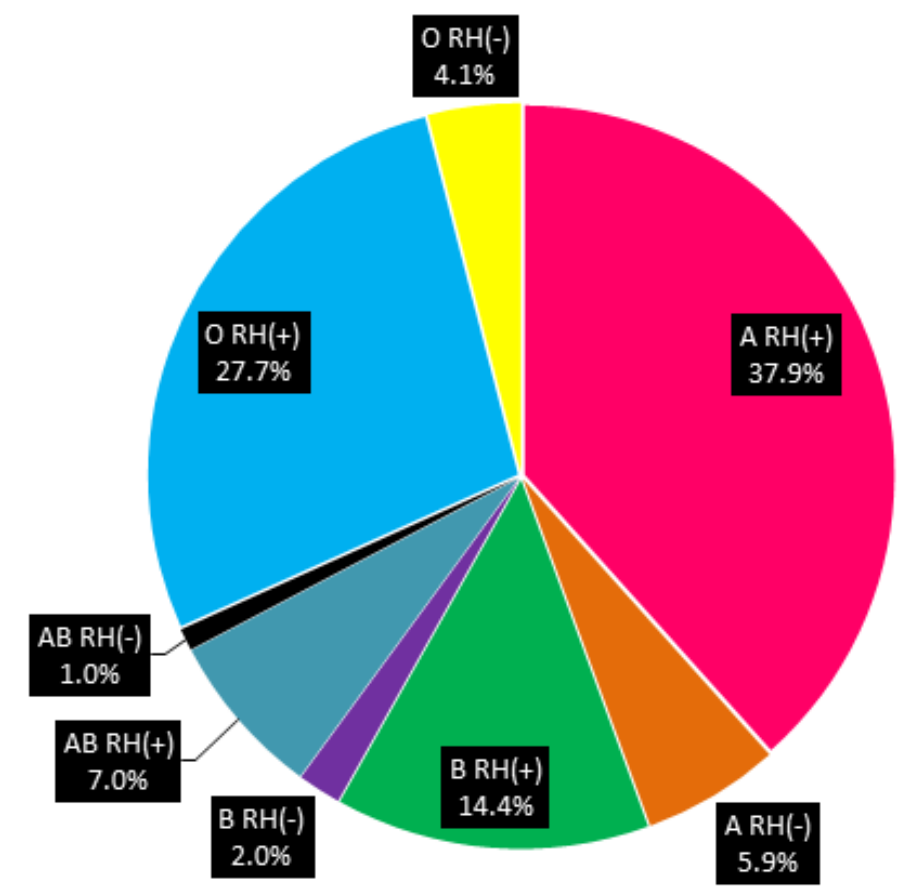

Figure 1: Distribution of blood groups in our region between the years 2009-2013.

When the blood groups of 99207 individuals, who were included in our study, were percentally assessed including all the years, it was seen that the A blood group had the highest proportion. The distribution of the blood groups that we obtained in our region is given in Figure 1. While the $\mathrm{Rh}$ factor was found positive in $87 \%$ of the individuals we examined in our study, it was detected as negative in $13 \%$ of them.

\section{DISCUSSION}

Blood transfusion was included in the medical application area after the determination of the blood group antigens and the invention of blood group compatibility tests between the receiver and donor ${ }^{18,27}$. There are over 600 blood group antigens 
that have been serologically identified ${ }^{18,27}$. Blood is a vital liquid in many application areas like medicine, judiciary and anthropology. The rate of benefitting from the blood and its products has increased in all over the world especially together with the extension of life spans22. It has been proved with studies that the blood group distributions can differ from each other in various countries. It is assumed that the certain blood group ratios are decreasing due to the difference in the blood group distribution, genetic drift, intersocietal gene flow and the infection observed only in specific regions ${ }^{10,28}$.

The A blood group takes place on the top with $43.8 \%$ in our study. According to the data of the General Directorate of Red Crescent Blood Services, the blood group A is placed on the top with $42 \%$ considering the blood group distribution throughout Turkey ${ }^{29}$. The A blood group results were specified between $36-46 \%$ in the studies conducted in our country ${ }^{25,30-35}$. It is noted that the A blood group and gene A frequency decreases slowly from the west towards the east of our country ${ }^{9}$. Considering all this information, it is clear that the results we obtained comply with our country data. Different ratios are reported for the blood groups in different regions of the world as well. It was noted that the A blood group ratio decreased down to $28.5 \%$ in Nepal, a South Asian country, while it was $37 \%$ in the United States of America ${ }^{36,37}$. The "0" blood group ranks as the second group with $31.8 \%$ in our study. Zerin et al. ${ }^{25}$, Balc1 et al. ${ }^{30}$, Dilek et al. ${ }^{31}$, Gül et al. ${ }^{32}$, Kuku et al. ${ }^{33}$, Temiz et al. ${ }^{34}$ and Özkasap et al. ${ }^{35}$ provided the following results for the $\mathrm{O}$ blood group, respectively: $34.69 \%$, 33.3\%, 30.8\%, 30.80\%, 37.23\%, $33.65 \%$ and $44.07 \%$. The "0" blood group ratio is $34 \%$ throughout Turkey ${ }^{29}$. The " 0 " blood group ratio that we found in our region complies with the other studies conducted in our country. The " 0 " blood group distribution differs between the regions in Turkey and it is seen that the " 0 " blood group distribution increases towards the west of the country. While the "0" blood group ratio took place on the top with $47 \%$ in the United States of America $^{36}$, this ratio was stated as $41.16 \%$ in the neighboring country $\operatorname{Iran}^{39}$ and as $35.5 \%$ in the South Asian country Nepal ${ }^{37}$.

The incidence rate of the $\mathrm{B}$ blood group was found as $16.4 \%$ in our study. Balc1 et al. ${ }^{30}$, Dilek et al. ${ }^{31}$, Gül et al. ${ }^{32}$, Kuku et $\mathrm{al}^{33}$. and Temiz et al. ${ }^{34}$ stated the following results for the incidence rate of the B blood group, respectively: $16.8 \%, 16.2 \%, 8.90 \%$, $14.9 \%$ and $18.53 \%$. It is seen that the data obtained for the B blood group in our study are parallel to our Country data. The B blood group results were noted as $12 \%$ in the United States of America and 9-17\% in Europe $^{36}$. It is observed that these results are close to the results we obtained in our study.

The lowest blood group ratio was detected as $A B$ in our region. The incidence rate of the $\mathrm{AB}$ blood group was found as $8.0 \%$ in our study. Blood group $A B$ results were specified between $2.60-9.20 \%$ in different studies conducted in our country $25,30-35$. This result, which we obtained in our region, seems similar to the results of the other studies. The results noted for the studies abroad are similar to our study ${ }^{36-}$ ${ }^{38}$. The $\mathrm{Rh}$ blood group positivity was determined as $87 \%$ in our study. Balc1 et al. ${ }^{30}$, Gül et al ${ }^{32}$. and Kuku et al. ${ }^{33}$ stated the following $\mathrm{Rh}$ positivity ratios, respectively: $89.9 \%, 87.20 \%$ and $89.3 \%$. Similar $\mathrm{Rh}$ positivities were reported in different studies conducted in our country as well ${ }^{25,31,34,35}$. Similar Rh positivities are also specified in the studies conducted in different parts of the world ${ }^{25,31,34,35}$. Marzban et al. ${ }^{39}$ stated the Rh positive blood group ratio of the Iranian public as $90 \%$ in their study. An Rh positivity by around $99 \%$ was mentioned in the study conducted by Pramanik and Adhikari ${ }^{37}$. The $\mathrm{Rh}$ positivity was seen as $96.66 \%$ in the study results of Pramanik and Pramanik S. ${ }^{38}$. It is observed that the $\mathrm{Rh}$ positivities we obtained in our study are similar to the data in our country and the world.

The increase in the human mobility leads to a rapid population differentiation in all over the world today. We therefore think that the regional blood group data must continuously be updated. We assume that knowing the $\mathrm{AB} 0$ and $\mathrm{Rh}$ blood group 
profiles of each region may be a facilitating factor for the blood and blood product supply and motivate the individuals with rare blood groups for blood donation. We also find it important to share the obtained statistical data with the society in order to increase the number of voluntary donors. For all these reasons, we are of the opinion that our study will make contribution to the literature related to the blood group distribution.

\section{REFERENCES}

1. Bayk M. Transfusion medicine and immunology, Türkiye Klinikleri J Hem Onc-Special Topics 2009; 2: 46-53.

2. Bayı M. How and where is it formed? Türkiye Kan Merkezleri Transfüzyon Derneği Bülteni 2011; 82: 13-6.

3. Uluhan R. Blood banking and transfusion history IV. Ulusal Kan Merkezleri ve Transfüzyon Tibbı Kongresi 14-18 Aralık 2011.

4. Dürüşken Ç. A General Overview of the Term "Psykhe" in the Ancient Age, Edebiyat Fakültesi Yayınlar1 1994; 29: 75-85.

5. Atamer T. History of blood transfusion 35. Ulusal Hematoloji Kongresi 2009; 148-54.

6. Dzik WH. The James Blundell Award Lecture 2006: Transfusion and the treatment of haemorrhage: Past, present and future. Transfus Med 2007; 17: 367-74.

7. Öğce F. Important points in blood transfusion for nurse. Journal of EU School of Nursing 2008; 24: 101-12.

8. Schwarz HP, Dörner F. "Karl Landsteiner and his major contributions to haematology" $\mathrm{Br} \mathrm{J}$ Haematol 2003; 121: 556-65.

9. Tan SY, Graham C. "Karl Landsteiner (1868-1943): Originator of AB0 blood classification" Singapore Med J 2013; 4: 243-4.

10. Akın G, Dostbil N. "Blood groups researches in Turkey" Ankara Üniversitesi Dil ve Tarih-Coğrafya Fakültesi Derg 2005; 45: 1-15.

11. Celkan T. Usage of blood and blood products and problems, XIII.
TPOG Ulusal Pediatrik Kanser Kongresi, Hemşire Programı 2004; 199-202.

12. Figl M, Pelinka LE. Karl Landsteiner, the discoverer of blood groups. Resuscitation 2004; 63: 251-4.

13. Knowles SM, Lewis SM, Bain BJ, Bates I. Blood cell antigens and antibodies: erythrocytes, platelets and granulocytes. Dacie and Lewis Practical Haematology. Ninth Edition, London, Churchill Livingstone 2001: 429-69.

14. Daniels GL. Cartron JP, Fletcher A, Garratty G, Henry S, Jørgensen J, Judd WJ, Levene C, Lin M, Lomas-Francis C, Moulds JJ, Moulds JM, Moulds M, Overbeeke M, Reid ME, Rouger P, Scott M, Sistonen P, Smart E, Tani Y, Wendel S, Zelinski T. International Society of Blood Transfusion Committee on terminology for red cell surface antigens: Vancouver report. Vox Sang 2003; 84: 244-7.

15. Cevizci S, Erginöz E, Yüceokur A. Readiness for blood donation and factors affecting behaviour to give blood: Review Türkiye Klinikleri J Cardiovasc Sci 2010; 22: 85-92.

16. Ördekçi S. Transfusion of blood and blood products, Medical Journal of Bakırköy 2006; 2: 113-22.

17. Erkurt MA, Özkan O. Erythrocyte suspensions and transfusion indications Türkiye Klinikleri $\mathrm{J}$ Int Med Sci 2007; 3: 50-3.

18. Guyton\&Hall. Blood groups. Medical Physiology 9. Ed. Nobel Tip Kitabevi Bölüm 35. 1996; 457-61.

19. Reid ME, Calhoun L, Petz LD. Erythrocyte antigens and antibodies In: Lichtman MA, Beutler E, Coller BS, Kipps TJ, Seligsohn U. Williams Hematology. Seventh Edition, New York, McGraw-Hill 2006: 2119-36.

20. Sloan SR, Benjamin RJ, Friedmanlain DF, Webb J, Silberstein L, Nathan DG, Ginsburg D, Orkin SH, Look AT. Nathan and Oski's Hematology of Infancy and Childhood. Sixth Edition, Philadelphia, Saunders 2003: 1709-56. 
21. Calhoun L, Petz LD. Erythrocyte antigens and antibodies. In: Williams Hematology, Beather E. sixth edition, New York, McGrawHill 2001: 1843-58.

22. Marantidou O, Loukopoulou L, Zervou E, Martinis G, Egglezou A, Fountouli P, Dimoxenous P, Parara M, Gavalaki M, Maniatis A. Factors that motivate and hinder blood donation in Greece. Transfus Med 2007; 17: 443-50.

23. Higgins C. "The risks associated with blood and blood product transfusion" British Journal of Nursing 2000; 9: 2281-90.

24. Yıldız Ç, Emekdaş G, Kanık A, Tiftik N, Solaz N, Aslan G, Tezcan S, Serin MS, Erden S, Helvacı İ, Otağ F. Why don't we donate blood. Turkish Journal of Infection 2006; 20: 41-55.

25. Zerin M, Karakılçık AZ, Nazlıgül $\mathrm{Y}$. Frequency of $\mathrm{ABO}$ and $\mathrm{Rh}$ blood groups in Sanliurfa region Journal of Harran University Medical Faculty 2004; 1: 15-7.

26. TR Ministry of Health National Blood and Blood Products Guide 2011; 266-87.

27. Hillman RS, Ault KA. Blood Component Therapy. In: Hillman RS, Ault KA, Rinder HM. Hematology in Clinical Practice. New York: Mc Graw Hill 2005; 431-41.

28. Dönbak L. Investigation of $A B O$ and $\mathrm{Rh}$ (D) gene frequencies in Kahramanmaraş area, KSÜ Fen ve Mühendislik Derg 2001; 4: 52-6.

29. Türk Kızılayı. General Directorate of Blood Services 2012; 97.

30. Balc1 YI. Ovet G, Covut İE, Goncu F, Yilmaz M, ABO and Rh blood groups frequency in Denizli province, International Journal of Hematology and Oncology 2010; 2: 103-5.

31. Dilek İ, Demir C, Bay A. Akdeniz $\mathrm{H}$ and Öner $\mathrm{AF}$. $\mathrm{ABO}$ and $\mathrm{Rh}$ blood groups frequency in men and women living in eastern Turkey. International Journal of Hematology and Oncology 2006; 1: 23-6.

32. Gül M, Sucu RI, Uyar T. The dis- tribution of $\mathrm{ABO}$ and Rh-D blood groups among blood donors in blood center of Sisli Etfal training and research hospital. KSÜ Tip Fak Derg 2005; 2: 42-4.

33. Kuku İ, Kaya E, Erkurt MA, Dikilitaş M, Yıldız R, Orhan M, Görgel A, Aydoğdu İ. ABO and Rh blood group distribution in Malatya region. Journal of Turgut Özal Medical Center 2004; 11: 213-5.

34. Temiz H, Altıntaş A, Gül K. Distribution of $\mathrm{ABO}$ and $\mathrm{Rh}$ blood groups in Diyarbakır, International Journal of Hematology and Oncology 2008; 4: 234-7.

35. Özkasap S. Dereci S, Şahin K, Dilek AR, Kalyoncuoğlu E, Zengin T, Özata B. Analysis of $\mathrm{ABO}$ and $\mathrm{Rh}$ blood groups distribution in East Karadeniz region of Turkey. Dicle Med J 2013; 40: 100-4.

36. Garratty G, Glynn SA, McEntire R. $\mathrm{ABO}$ and $\mathrm{Rh}$ (D) phenotype frequencies of different racial/ethnic groups in the United States. Transfusion 2004; 44: 7036.

37. Pramanik T, Adhikari P. Trend of blood group distribution among the different ethnic groups of Kathmandu Valley. Nepal Med Coll J 2006; 8: 248-9.

38. Pramanik T, Pramanik S. Distribution of $\mathrm{ABO}$ and $\mathrm{Rh}$ blood groups in Nepalese medical students: a report. East Mediterr Health J 2000; 6: 156-8.

39. Marzban M, Kamali MS, Hosseinbasi T. Blood groups of the people of Ahwaz, Iran. Anthropol Anz 1988; 46: 83-9. 